WORLD CONGRESS ON OSTEOPOROSIS, OSTEOARTHRITIS AND MUSCULOSKELETAL DISEASES

\title{
VIRTUAL CONGRESS
} August 26-28, 2021
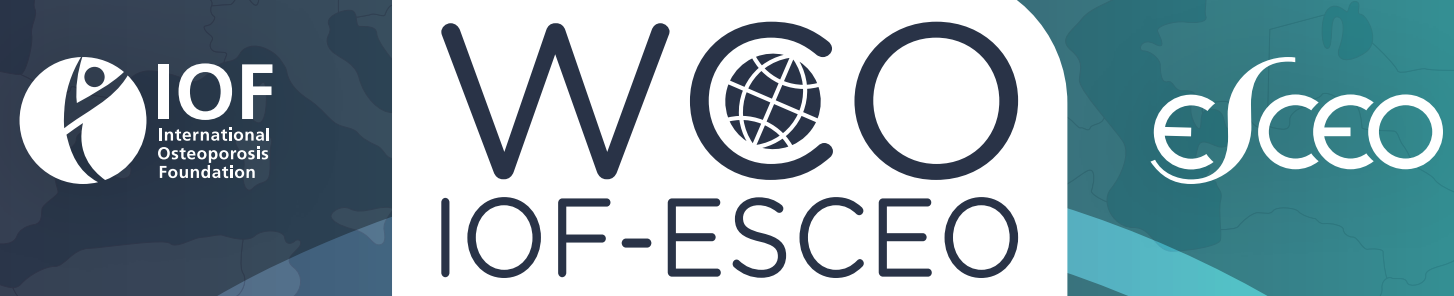

\section{VIRTUAL}

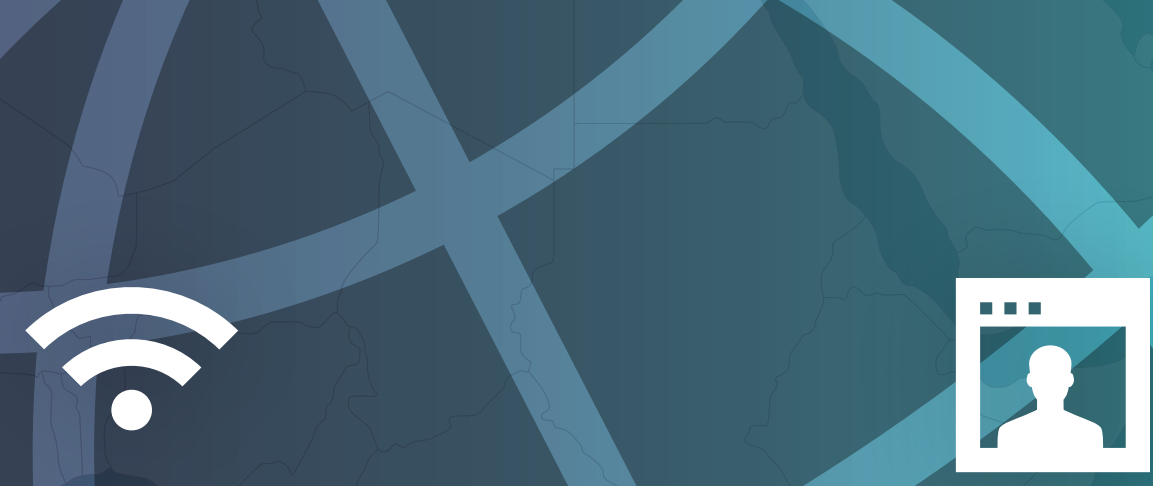




\section{P544}

\section{EFFECT OF COMBINED THERAPY ON THE}

INFLAMMATION BIOMARKERS IN PATIENTS WITH

RHEUMATOID ARTHRITIS

\section{S. S. Spitsina ${ }^{1}$, L. N. Shilova ${ }^{2}$, A. A. Trofımenko ${ }^{3}$, E. E.} Mozgovaya $^{3}$, S. A. Bedina ${ }^{3}$

${ }^{1}$ Federal State Budgetary Institution "Research Institute of Clinical and Experimental Rheumatology A.B. Zborovsky"; Volgograd State Medical University, ${ }^{2}$ Volgograd State Medical University, ${ }^{3}$ Federal State Budgetary Institution "Research Institute of Clinical and Experimental Rheumatology A.B. Zborovsky”, Volgograd, Russia

Objective: To evaluate efficiency of combination therapy including infliximab (IF) in RA patients by means of inflammation markers (ESR, CRP) and serum pro-inflammatory (TNFa, IL-1) cytokines.

Methods: 18 patients with RA diagnosis were included in the 30 -week study. The average age of patients was $46.0 \pm 8.4 \mathrm{y}$, disease duration $13.2 \pm 5.3 \mathrm{y} .83 .3 \%$ of patients were seropositive for rheumatoid factor, $66.8 \%$ were ACCP-positive. Each patient was treated with methotrexate (MT) $12.5-20 \mathrm{mg} /$ week. IF was administered at the dose of $3 \mathrm{mg} / \mathrm{kg}$, according to the common scheme. Patients were examined at week 0 (before the inclusion), week 14, and week 30 after beginning of IF therapy.

Results: All patients had DAS28-CRP(4)>5.6. ESR and CRP have decreased by the 30th week. The average VAS score at week 0 was $68.3 \mathrm{~mm}$, at week $30-26.0 \mathrm{~mm}$. There were $50 \%$ of patients with good response to IF therapy, $33.3 \%$ with moderate one, and $16.7 \%$ without significant effect. Serum concentrations of pro-inflammatory cytokines (TNFa, IL-1) at week 30 were substantially decreased compared to initial levels along with trend of RF, ESR and CRP normalization as well as improvement of clinical manifestations (Table).

Table. Dynamics of clinical and laboratory markers in combination therapy $(\mathrm{Me})$

\begin{tabular}{|l|l|l|l|}
\hline Indicator & 0 week & 14 week & 30 week \\
\hline RF, IU/I & $\begin{array}{l}45295[12830 ; \\
134920]\end{array}$ & $\begin{array}{l}25375[7080 ; \\
80350]\end{array}$ & $\begin{array}{l}9920[5600 ; \\
110230]\end{array}$ \\
\hline ESR, mm/h & $37[4 ; 40]$ & $10.5[3 ; 51]$ & $10[2 ; 30]$ \\
\hline CRP, mg/l & $\begin{array}{l}20.8[4.6 ; \\
194.8]\end{array}$ & $2.65[0.4 ; 33.4]$ & $5.2[1.1 ; 9]$ \\
\hline DAS28-CRP(4) & $\begin{array}{l}5.63[4.38 ; \\
6.24]\end{array}$ & $4.5[2.5 ; 6.76]$ & $\begin{array}{l}3.58[2.25 ; \\
4.91]\end{array}$ \\
\hline TNFa, pg/ml & $\begin{array}{l}6.92[3.46 ; \\
11.03]\end{array}$ & - & $\begin{array}{l}2.09[1.74 ; \\
4.06]\end{array}$ \\
\hline IL-1, pg/ml & $\begin{array}{l}8.18[4.64 ; \\
10.12]\end{array}$ & - & $3.25[2.1 ; 6.45]$ \\
\hline
\end{tabular}

Conclusion: Tight correlation between shifts of TNFa, IL-1 levels with common clinical and laboratory markers of RA activity against the background of combined IF-MT treatment enables us to use these innovational biomarkers for RA treatment monitoring.

\section{P545}

\section{RISK OF FRACTURE IN GLUCOCORTICOID REQUIRING DISEASES: AN ANALYSIS ON A NATIONWIDE DATABASE

\author{
M. Rossini ${ }^{1}$
} \\ G. Adami ${ }^{1}$, A. Fassio ${ }^{1}$, E. Bertoldo ${ }^{1}$, O. Viapiana ${ }^{1}$, D. Gatti ${ }^{1}$,}

${ }^{1}$ Rheumatology Unit, University of Verona, Verona, Italy

Objective: Glucocorticoid-induced osteoporosis (GIOP) is the most common form of secondary osteoporosis. Glucocorticoids (GCs) are prescribed to patients affected by inflammatory diseases that are themselves independent risk factors for osteoporosis. The aim of the present study was to determine the risk of fracture associated with chronic GC use and a variety GC requiring diseases.

Methods: We conducted a retrospective cohort analysis of a nationwide cohort (DeFRACalc79 database). DeFRACalc79 is an algorithm for the estimation of the fracture risk that considers many risk factors, including glucocorticoid use. We used multivariable regression analysis adjusting for several risk factors for fracture and GC intake to estimate the independent role of glucocorticoid requiring illnesses on fracture risk.

Results: We found that GCs, at doses $\geq 5 \mathrm{mg} / \mathrm{d}$ for $>3$ months, were associated with a $60 \%$ increased risk of vertebral or hip fractures (aOR 1.58, 95\% Cl 1.43-1.76) and with a $30 \%$ increased risk of fragility fractures of any kind (aOR $1.32,95 \% \mathrm{Cl} 1.20-1.45)$. We found that patients with rheumatoid arthritis (RA), connective tissue diseases (CTDs), chronic obstructive pulmonary disease (COPD) and neurological diseases (ND) were at greater risk of vertebral or hip fracture (crude ORs 1.31, 1.20, 1.92 and 2.97 respectively). After adjusting for potential confounders (i.e., GCs, age, BMD levels, menopause and familiar history of fractures) COPD and ND remained significantly associated with an increased risk of vertebral or hip fractures (aORs $1.33,95 \% \mathrm{Cl} 1.18-1.49$ and $2.43,95 \% \mathrm{Cl}$ 2.17-2.74). RA, COPD, IBD and ND also significantly increased the risk of non-vertebral, non-hip fractures (aORs 1.23, 1.42, 1.52 and 1.94 respectively). Figure shows the risk of fracture in different diseases.

Conclusion: GC requiring diseases were independently associated with an increased risk of fractures: COPD and ND with both vertebral and non-vertebral fracture risk while RA and IBD were inde- 